\title{
APPLIED SCIENTIFIC TOOLS OF IMPROVING THE EFFICIENCY OF ECONOMIC ENVIRONMENT OF CONSTRUCTION ENTERPRISES OPERATION IN THE PROJECT DEVELOPMENT SYSTEM
}

\section{Ryzhakova G. M.}

\section{INTRODUCTION}

One of the key problems hampering the housing construction development in Ukraine is the lack of investment. The current crisis in the construction area has been caused by investors' mistrust of developers who, having raised funds, substantially violate their obligations. Investors face a limited choice of investment mechanism, tending to invest only in the areas where market players and the state have created proper conditions for business transparency and reliability and property rights protection. A need arises in researching the issues of investment of residential construction, introducing market mechanisms for investing in housing development by attracting external and internal investment resources pursuant to minimizing investors' risks, improving the investment environment and activization of the role of the economy's banking sector.

Recent studies of the described range of problems demonstrate that in the context of the financial crisis, it is necessary to adopt a range of legislative documents to facilitate the construction industry development.

Currently, the theoretical and methodological framework for the coverage of the issues connected with investing into the housing construction by attracting private funds, as well as the choice of the mechanism of investing into housing construction is debated among domestic scientists and experts. The issues of investment activities were researched in the works of such Ukrainian scientists as: I.O. Blank, S.D. Bushuiev [1], N.S. Bushuieva [1], A.F. Hoiko [2], N.O. DotsenkoBilous [3], Z.V. Zadorozhnyi, Ya.D. Krupka, P.M. Kulikov [4], I.P. Otenko, T.S. Marchuk [5], S.P. Stetsenko, V.O. Pokolenko [6], I.V. Popovychenko, M.S. Pushkar, G.V. Ryzhakova [7], T.V. Savchuk, D.O. Chernyshev [8], Yu.A. Chupryna [9], A.S. Fesun [10] and others.

However, despite a large number of researches on this topic exist, a lot of them are of a general descriptive, conceptual nature and does not account certain industrial dimensions of applied financial management, in particular, the definition of the essence of the concept of investment and disclosing the 
features of the organizational procedure of implementing various investment mechanisms in housing construction; the issue of selecting the least risky mechanism of attracting funds to invest into housing construction, as well as each mechanism's place and role in the domestic system of investing into housing construction; adapting western mechanisms of investing into the housing facilities construction to the current environment in which domestic construction companies operate, and their consolidation with domestic methodological and applied best practices in implementing investment and construction projects etc.

The purpose of the present article is providing theoretical and methodological background and applied development of an alternative mechanism of investment into housing construction aimed at expanding the role of investments in the activities of institutional investors - stakeholders of a developer construction project (DCP), which will serve as an additional investment resource for domestic construction companies in the current and future environment and facilitate the increase of DCP investment attractiveness.

\section{Funds trust management in the system of construction funding}

In the market economy, the organization of attracting investment into rather resource-intensive housing construction, is becoming one of the directions of any construction company's areas of activity providing a successful implementation of housing sphere construction projects. This activity gains special importance now, in the context of the financial and economic crisis in Ukraine, when it is necessary to consider the impact of a number of factors on it. First, since the reforms in Ukraine were introduced, the financial standing of construction companies deteriorated, and an acute working capital deficit emerged. Second, the scarcity of working capital was increased due to the rising costs of credits, national currency devaluation and progressing inflation. Third, as Ukraine is still at the early stage of forming a market economy, until recently domestic construction companies were able to use only a limited range of investment attraction mechanisms. A gradual development of market relations has diversified the forms and methods of financing operating assets of the construction companies which transited to independent economic policy formation.

The range of problems of the theoretical framework and practical mechanism of investing into housing construction (fig. 1) as a basic condition of investment support of construction companies' development is one of the most disputed in the modern science. Under the existing circumstances the significance of investment undergoes qualitative transformation. It evolves from a passive distribution mechanism of newly formed value into the main regulator of modern enterprises' economic 
activity. In the economic literature, the definition of the investment mechanism is not yet well established.

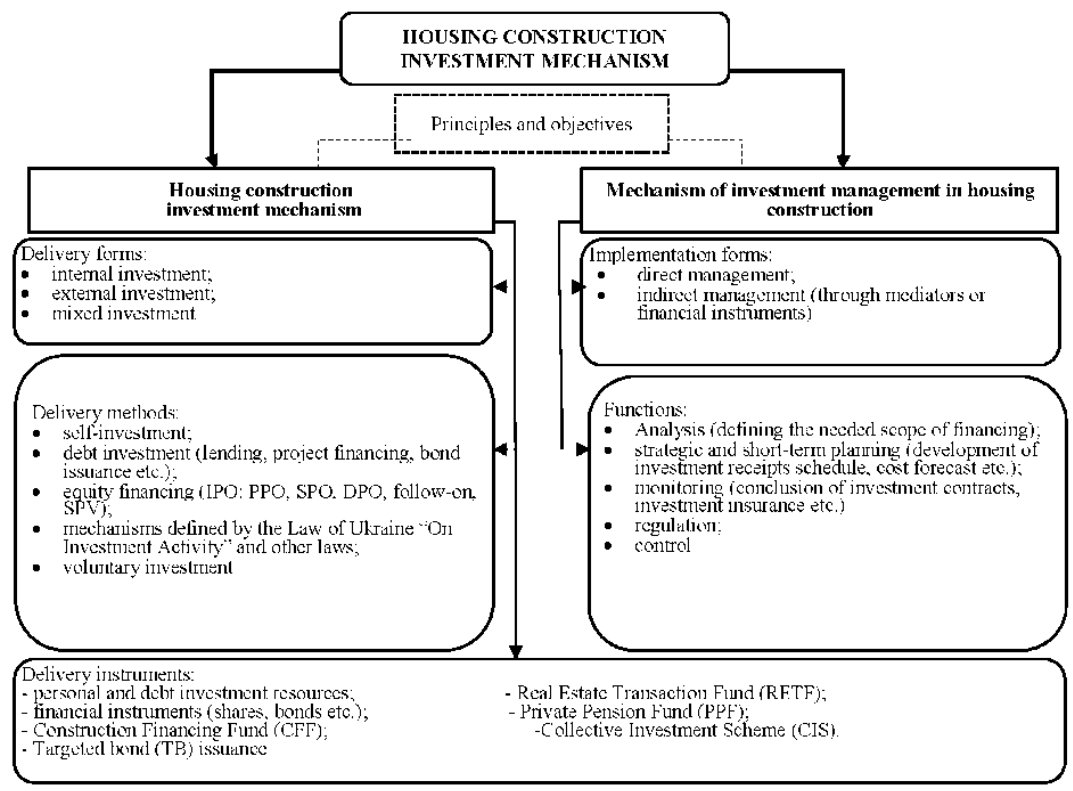

\section{Fig. 1. Component-based structure of the housing construction investment mechanism}

In the legislative environment, the term "housing construction investment" is mentioned in the Law of Ukraine "On Investment Activity" of 18.09.1991 No 1560-XII (as amended), but it defines only the sources of investment activities financing (Article 10). From the standpoint of a construction company, the term "economic activity investment" can be found in the Commercial Code, where it is defined as a "long-term investment of various kinds of property, intellectual assets and property rights in objects of economic activity with the aim of revenue (profit) generation or achieving other social effect." Also, the term "investment activity" is mentioned in the National Provisions (Standards) on Accounting No 1 "General Requirements for Financial Reporting" and means acquisition and disposal of those non-current assets and those financial investments which do not constitute a part of cash equivalents.

The most crucial aspect of investment into construction is the choice of the best depositing mechanisms. Despite having several common features, 
each of them has its specifics which depend on the developer's legal status, financing procedure, documents which are executed, the aim pursued by the parties etc. The list of legal financing mechanisms for housing construction is established by the mentioned Law of Ukraine № 1560-XII. Thus, by virtue of part 3, Article 4 of the Law № 1560-XII, the ways of attracting investments are: - construction financing funds (further-CFF); - real estate transaction funds (RETF); - co-financing institutions (CFI); - special purpose bond (SPB) emissions at enterprises. The same source establishes that other ways of construction financing are defined exclusively by laws. However, despite the express prohibition stipulated by Article 4 of the Law of Ukraine "On Investment Activities", in practice, developers often use socalled "parole investment contract", i.e., contracts on investment (common share in construction financing) and purchase and sale of property rights to real property under construction. Indeed, as the Civil Code of Ukraine accords the right to conclude any kinds of contract not expressly prohibited by the current legislation of Ukraine, a situation can be construed in an ambivalent manner and conclude the mentioned contracts using the provisions of the Civil Code on the freedom of contract. To avoid negative consequences, only legal investment mechanisms should be used which are listed in part 3 of Article 4 of the Law № 1560-XII. So, the choice of a specific way of construction financing becomes key for an investor.

Upon bringing amendments to the legislation on investment activities, the possibility of concluding direct investment contracts for housing construction was excluded, and the list of investment methods was limited only to the mechanisms provided for by Article 4 of the Law of Ukraine "On Investment Activity". As a result of these amendments, a legislative prohibition was imposed on concluding investment contracts in the housing construction sphere and promotion of the cases of using financial mechanisms - housing financing funds and real estate transaction funds provided for by the Law of Ukraine "On Financial and Credit Mechanisms and Property Management during House Building and Real Estate Operations" of June 19, 2003, 978-IV.

The peak of commissioning of houses in the country was registered in 2017, amounting to 5.9 million square meters of commissioned housing. In 2018, the amount of constructed housing in Ukraine declined by $25 \%$, and in the first quarter of 2019, the market shrank by another $4 \%$. Over $30 \%$ of purchases of housing built in Kyiv are conducted under forward contracts, around 20-25\% of developers use property bonds when selling newly built housing, $10 \%$ of housing are sold via construction financing funds (CFF) ${ }^{1}$.

\footnotetext{
1 Housing construction schemes in Kyiv. Electronic resource. Available at:
} http://directinvest.com.ua/ru/2018/05/11/sxemi-finansuvannya-budivnictva-zhitla-v-kiyevi: 
These mechanisms belong to the so-called schemes of investing into purchase. The rest of new buildings in Kyiv are sold via the mechanism of real estate purchase, namely via concluding real estate purchase and sale contracts or property rights purchase and sale contracts.

No consensus exists among researchers of history of jurisprudence as to the genesis of the trust management concept. Most scientists held a general view that trust management stem from the British tradition, of which a special concept of trust as a separate scheme of legal relations is characteristic. The classical Anglo-America form of trust management foresees that a trustee reserves the legal right of title and can use both the respective property and any profit thereon. In contrast to the principles of the orthodox continental law, the British legal doctrine allows for a so-called "splitting" of property, when one object can in fact have two owners - a conventional one and a trust one. The adoption of the Decree of the Cabinet of Ministers of Ukraine "On Trust Institutions" No 23-93 of 17.03.1993 was the first attempt to legalize trust relationships in Ukraine. Legislative uncertainty, the fact that no legal expertise of the draft Decree was held, the lack of a clear system of control of financial intermediaries' activities, irresponsibility of local executive bodies were conductive to the active creation and unlawful activities of pseudo-trust institutions, trusts, insurance companies, investment funds and other business entities acting to attract property and, which is the worst, citizens' money. The fact that no timely preventive measures were taken by authorities, regulatory and lawenforcement bodies led to proliferation in Ukraine of financial fraud on a scale so large it was dangerous for the state, rip-off of the population, chiefly socially vulnerable. In fact, trusts as a tool of trust management were fully discredited by economic realities. Further development of management relations can be divided into two stages: the first one - 1996-2001 - was signified by the creation of the legislative framework for operations on securities management; the second one - 2002-2005 - by the creation of the legislative framework for operations on money management in financial and credit sphere. Specialists were ambiguous as to the introduction of the category of trust property into the Ukrainian legal system. Involving developers in the use of the financial schemes defined by the Law on property management during house building is largely of the nature of regulatory coercion. It is the strict legislative restrictions prompted most developers to introduce the mechanisms of trust management into their work. Considering the legislative ambiguity of the category of trust management characteristic of the domestic legal system, and considering the special character of industry-specific legislation, the term "trust management of property in housing construction" should be defined as a statutorily prescribed (by the Law of Ukraine "On Financial and Credit Mechanisms 
and Property Management during House Building and Real Estate Operations") set of principles, legal and organizational framework for attraction of investor's funds into management based on the enforcement of the trust property right with the aim of housing construction financing. The implementation of trust management of property is provided for by the legislation through the use of CFF mechanisms and attraction of funds to housing construction via the use of securities emitted by the trustee of a real estate transaction fund (RETF). Despite the distinct kinship of these entities, their principal distinction is that trustors buying RETF certificates do not aim to obtain housing. It is worth mentioning that trust management is a separate legal tool different from such categories as management, operational management, and the right of full economic management, which is common in the modern economic use.

The forward contract scheme (table 1) gained special popularity among Kyiv developers 2-3 years ago. A derivative is a standard document certifying the right and/or obligation to purchase or sell, on certain conditions, in future, securities, funds, tangible assets (in our case immovables) or intangible assets. As a rule, when selling immovables in new houses through forward contracts, the agreement is concluded with the participation of asset management company in two stages:

- registration of the forward contract on a commodity exchange;

- conclusion of an contract of purchase and sale of property rights between the parties to the agreement.

Table 1

Key advantages of the forward financing scheme

\begin{tabular}{|c|c|}
\hline For developer & For investor \\
\hline $\begin{array}{l}\text { - allows to organize construction as a } \\
\text { partnership, when one company owns the } \\
\text { site, and the other holds all the permits for } \\
\text { construction; }\end{array}$ & $\begin{array}{l}\text { - allows to avoid the risks of double sales } \\
\text { (investor is granted an exclusive right of } \\
\text { preference in purchasing an apartment under } \\
\text { the contract of purchase and sale of property } \\
\text { rights); }\end{array}$ \\
\hline $\begin{array}{l}\text { - when working with forward contracts, a } \\
\text { developer needs no manager, as is the case } \\
\text { with using construction financing funds; }\end{array}$ & \multirow{2}{*}{$\begin{array}{l}\text { - fraudulent activities on the real estate } \\
\text { market are minimized (forward contracts are } \\
\text { sold on a commodity exchange, which } \\
\text { beside providing control of agreements, } \\
\text { keeps records of the property rights for } \\
\text { forward contracts); }\end{array}$} \\
\hline $\begin{array}{l}\text { - paperwork is simplified (no need to issue } \\
\text { bonds, involve qualified and expensive } \\
\text { specialists both in the sphere of securities and } \\
\text { in the sphere of accounting and taxation); }\end{array}$ & \\
\hline $\begin{array}{l}\text { - the risk of changes is diminished by fixing } \\
\text { the price of the underlying asset expressed in } \\
\text { dollars, }\end{array}$ & $\begin{array}{l}\text { - helps to avoid related services and } \\
\text { additional costs (for notary services etc.) }\end{array}$ \\
\hline
\end{tabular}

It must be emphasized that currently no scheme of financing housing under construction exists in Ukraine which would protect investors 
completely. There are more risky and less risky variants. There are also variants which are more lucrative for developers, and those in which developers are compelled to adhere to due to various reasons.

\section{Diversification of investment resources forming tools in the context of increase of construction companies' activities}

Today, construction companies face a large number of factors containing their investment and construction activities (fig. 2). These factors, which are of economic, political and social origin, include legislative framework instability, excessive taxation, crime and corruption, lack of a well-designed system of measures to provide economic and legal protection of investors' interests; high inflation rates, which renders mid- and, even more so, longterm investments inefficient, population's low purchasing power, high custom fees, bureaucracy and incompetence of authorities, business partners' failure to pay, insufficient insurance guarantees provided by the state; underdeveloped infrastructure; limited range of services provided by local banks, shortage of staff; lack of production facilities etc.

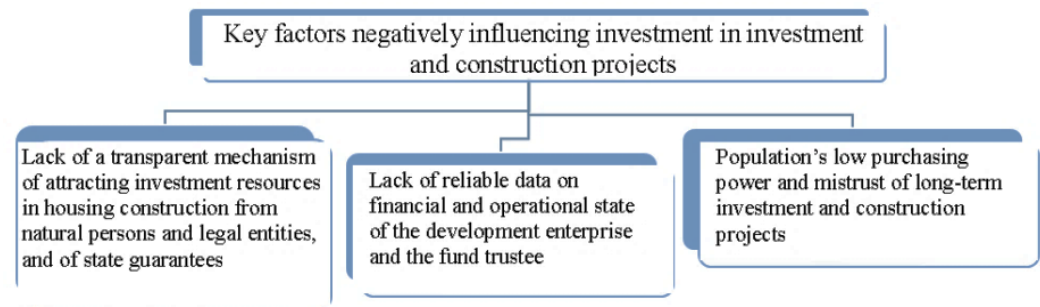

\section{Fig. 2. Key factors negatively influencing investment in investment and construction projects}

Investment risk value allows to demonstrate the probability of loss of investments and revenue therefrom. The following kinds of risks are distinguished: economic (trends in a region's economic development); financial (degree of balance of the regional budget and the enterprise's finances); political (distribution of political leaning among the population based on the results of the latest parliamentary and local elections); social (the level of social tension); ecological (the level of environmental pollution).

All these factors diminish investment attractiveness and has a negative impact on the investment activities of construction companies. When launching construction of residential property, developers are obliged to choose the mechanism of financing the project in line with their interests and the law. Before investing into a construction project, investors also must 
decide on the guarantees to protect their investments. The main point of coinvestment is pooling and accumulating the finances of small investors in a so-called "basket". These funds can be used for various purposes, in this case for real estate development. The use of co-investment institutes is a fairly common mechanism, whose advantages, besides the conformity of this investment method to Article 4 of the Law of Ukraine "On Investment Activities", include the legal mechanism of taxation optimization. In particular, funds (investment contributions) received by a corporate fund from an investor which is a natural person who wishes to participate in real estate development, are shared funds exempt from taxation according to the provisions of sub-item 141.6.1 of item 141.6, Article 141 of the Tax Code of Ukraine. This position was supported in the letter of the State Fiscal Service of Ukraine of 12.12.2017 №2938/6/99-99-15-02-02-15/IPK. However, the creation and functioning of such financing mechanism calls for significant expenditures, and thus is unavailable for many developers. The method of financing real estate construction through the system of co-investment institutes is unable to meet investors' needs in residential premises. In spite of the existence of legislative possibility to repurchase co-investment institute securities by means of the real estate acquired by it, it is recognized that the securities of a corporate investment fund (shares) can be repurchased only by paying for them with the company's money, which makes this option inexpedient and, as a result, leads to the lack of practice of repurchase of emitted investment certificates by an asset management company of a share fund through payment for these certificates by the real estate belonging to such company.

The construction investment mechanisms ignored by developers and investors alike also include the mechanism using the funds of PPFs (private pension funds). As of 31.12.2018, within the structure of invested pension assets the share of immovable property items with the index of UAH 17.7 million, or $0.04 \%$, holds only the fifth place in the structure of the investment portfolio of Ukraine. The deterrent, along with PPFs' passive investment strategy, is a complex system of PPF creation, which explains why the mechanism of investing into residential construction through PPF is the least accepted of all similar mechanisms.

Also, the mechanism of investing into residential construction through private pension funds cannot be considered an effective one. According to the legal definition of a pension payment, the latter is only provided in monetary form, therefore monetary fund investors into housing construction financing through private pension funds do not receive residential premises.

The system of housing construction investment through emission of interest-free (targeted) bonds (TB) is characterized by high risks and extra expenditures for developers (search for investors and security broker, 
issuance costs, floatation and redemption of bonds, risks of non-floatation of emitted securities etc.). Introduction of this mechanism is additionally complicated by the lack of proper statutory regulation of relations in the sphere of circulation redemption of targeted (housing) bonds.

The most common and popular housing construction investment mechanism in Ukraine is CFF. This scheme is strictly regulated by the Law of Ukraine "On Financial and Credit Mechanisms and Property Management during House Building and Real Estate Operations” of 19.06.2003 № 978-IV (further - the Law). The essence of the mechanism lies in the following:

- investor (potential housing owner) transfers property (funds) upon trust to a trustee in the aim of construction financing. This transfer is executed by a contract.

- The trustee enters into contractual relations with a developer who undertakes to construct an item of immovable property and hand a specific apartment into the trustee's ownership,

- the developer's surety bond before the trustee is mortgage;

- two contracts are concluded between the trustee and the developer:

1) transfer of property rights;

2) agency contract with suspension conditions.

According to the conditions of the above transactions, when the developer breaks the obligations it has undertaken, the trustee is endowed with a wide range of rights up to changing the developer.

At the same time, if a risk of developer's breach of its obligation exists, all property rights to the real estate are vested with the trustee based on the assignment agreement.

It is worth mentioning that, in spite of the general decrease of the number of companies holding a license for creating CFF, the total number of trustors and the amount of funds attracted via this mechanism grow steadily, which cannot be said about the mechanism of housing construction investment via RETF, although it can be put down to the peculiarities of each of the mechanisms. Thus, the first one is used by a real estate by investor for acquisition of ownership of an item, and the second one - for deriving profits form real estate transactions. Such type of investments is not common in our country, which explains the lack of developers' interest in this mechanism of investment.

As of 30.06.2019, as many as 52 financial companies had valid licenses for economic activities in the sphere of financial services provision, i.e. in property management for construction project financing and/or operations with real estate in accordance with the Law of Ukraine "On Financial and Credit Mechanisms and Property Management during House Building and Real Estate Operations". The total number of property trustors who concluded contracts with trustees on participation in construction financing 
funds (CFF) as of 30.06 .2019 is 28,156 persons, among which 27,968 are natural persons and 188 are legal entities ${ }^{2}$.

The analysis of the way of construction financing in the form of CFF provided for by the above-mentioned Law of Ukraine, leads to the conclusion that in the case of investment by creating a type B CFF, additional risks and significant costs are imposed on the trustee, which greatly discouraged the use of this legal mechanism. The dynamics of the change of the number of CFF trustors and their contributions is shown on Figure 3.

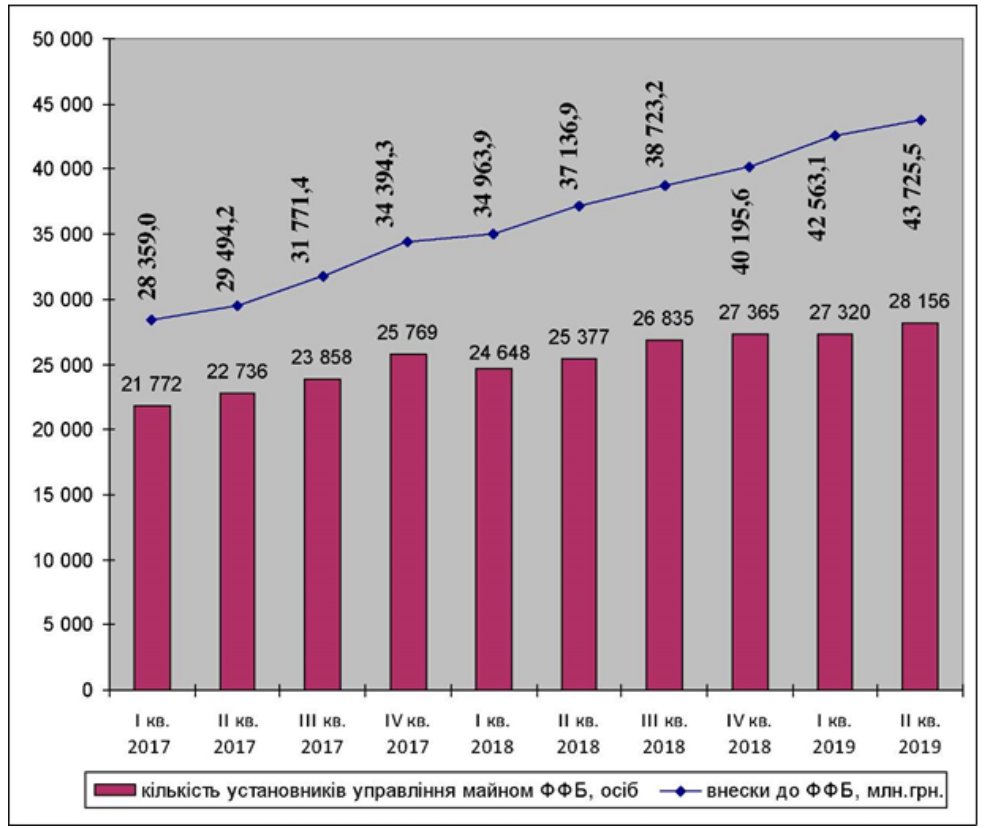

Fig. 3. Dynamics in the number of CFF trustors and attraction of funds from CFF trustors

In recent years, gradual rise of the number of CFF trustor and the flow of their contributions to CFF is observed. As compared with the similar period in 2018, as of 30.06 .2019 , the number of CFF trustors grew by $11.0 \%$ (2,779 persons). As of 30.06 .2019 , the amount of contributions made by CFF trustors reached UAH 43,725.5 million, which is $17.7 \%$ (UAH 6,588.6

\footnotetext{
${ }^{2}$ Official web-site of the National Committee on State Regulation in the Sphere of Markets of Financial Services https://www.nfp.gov.ua/files/OgliadRinkiv/FK/FK_I\%20kv
} 
million) more as compared with the same date in the previous year. Of these, the amount of contributions made by trustors - natural persons reached UAH $35,290.7$ million $(80.7 \%$ of the total amount of construction financing sources) as of 30.06.2019.

As of 30.06.2019, the amount of funds handed over to developers to construct facilities via the CFF mechanism reached UAH 25,530.4 million or $58.8 \%$ of the total amount of construction financing (table 2).

Table 2

Construction Financing with CFF

\begin{tabular}{|c|c|c|}
\hline Construction financing & As of 30.06.2019 & Ratio, \% \\
\hline On the fund's current account in a bank, million UAH & 374.2 & 0.9 \\
\hline On a deposit account in a bank, million UAH & $16,571.6$ & 38.2 \\
\hline $\begin{array}{c}\text { Handed over to developer to construct facilities, } \\
\text { million UAH }\end{array}$ & $25,530.4$ & 58.8 \\
\hline $\begin{array}{c}\text { Amounts written off for payments and cash management, } \\
\text { accrued interests on this account, million UAH }\end{array}$ & 42.5 & 0.1 \\
\hline Remuneration for trustee, million UAH & 882.2 & 2.0 \\
\hline Total amount of construction financing & $43,400.9$ & 100.0 \\
\hline
\end{tabular}

As of 30.06.2019, only one financial company holds a permit allowing to emit real estate transaction fund certificates (further - RETF certificates).

Table 3

Construction Financing with RETF

\begin{tabular}{|c|c|c|}
\hline Sources of construction financing & $\begin{array}{c}\text { As of } \\
\mathbf{3 0 . 0 6 . 2 0 1 9}\end{array}$ & Ratio, \% \\
\hline $\begin{array}{c}\text { Amount of contributions made by trustors } \\
\text { (natural persons), million UAH }\end{array}$ & $35,290.7$ & 80.7 \\
\hline $\begin{array}{c}\text { Amount of contributions made by trustors (legal entities), } \\
\text { million UAH }\end{array}$ & $8,434.8$ & 19.3 \\
\hline Trustee's own funds used to finance construction, million UAH & 17.7 & 0.04 \\
\hline $\begin{array}{c}\text { Total amount of sources of construction financing, } \\
\text { million UAH }\end{array}$ & $\mathbf{4 3 , 7 4 3 . 2}$ & $\mathbf{1 0 0 . 0}$ \\
\hline
\end{tabular}

The analysis of the ways of investing into housing construction provided for by the law (in the forms of co-investment institute, PPF, emission of noninterest-bearing (special purpose) bonds, CFF and RETF) testifies that, despite the availability of a number of such legal mechanism, the single genuinely functioning way of financing able to satisfy investors' needs in residential premises is investing money in housing construction in the form of type A CFF. Other investment modes either do not envisage the provision of residential property (private pension and corporate funds or RETF certificate emission) or are too complicated and inexpedient for developers (housing obligations emission) or trustees (type B CFF mechanism and the 
share fund system), which is why the practice of using these housing construction investment modes is virtually non-existent in Ukraine.

The system of housing construction financing via attraction of CFF (RETF) funds is aimed to ease the significant financial and legal tension in the housing segment of the market. However, the results of the conducted study helped reveal and systematize the problems of property management in the sphere of housing construction, which include lack of proper regulation of enabling properties of the "developer" and "customer" categories; lack of legal clarity as to the identification of the types of contracts concluded between the trustor and developer, especially as to the definition of indicators of targeted use of investors' funds; lack of regulation of identification of the risks which may divest a developer of its status; lack of clarity on the matters of procedures of provision and remuneration of auditor's services, which lowers the transparency of the CFF (RETF) system on the whole; restrictions as to the choice of banking institutions by the developer; absence of a defined algorithm of circulation of property rights in the system of CFF (RETF). The responsibility imposed by the Law on Property Management on CFF (RETF) trustees seems non-symmetric. As this Law does not have separate provisions on the trustees' liability, investors have to join general civil practice. Considering the complexity of the procedure of engaging a trustee in a direct property liability, there are grounds to verify that a CFF (RETF) trustee bears no real onus of property liability before trustors, placing in on the developer instead. However, under the Law on Property Management during House Building, a developer does not enter into contractual relationships with an investor. Thus, the investor is deprived of important leverage of influencing its contractor. Considering this, it would be rational to ensure a more equitable distribution of liability between the trustee and the developer, and putting the developer and investor on the same civil field via signing of bi- or trilateral agreements. The sphere of property management with the use of such securities as RETF certificates is characterized by extremely attractive tax incentives. Such situation is also common in international practice. However, in contrast to world traditions, the domestic system of RETF investment is not regulated as to other important parameters (the ratio of main income operations, the proportions of profit distribution). This creates potential risks of abuse in this investment area.

Under part 1 of Article 18 of the mentioned Law, the State guarantees the stability of environment for investment activities, enforcement of rights and legal interests of its subjects. At the same time, according to the data of the Kyiv city information and analytical system for urban development support "Kyiv Urban Development Cadaster", 67 unlawful development sites were 
found in Kyiv as of January $2018^{3}$. Depositing in financing of real estate is risky and is only justified if the construction has been finished. At the same time, much depends on the integrity of the developer or the asset management company (AMC). Many banks acted as administrators of construction financing funds (CFF), but because of the crash of a large number of banks (when many banks' licenses were revoked) these financing funds were left without administrators. Investors hare left with a single way to finish the construction - through enforced change of such AMC.

The system of housing construction financing via attraction of CFF (RETF) funds is aimed to ease the significant financial and legal tension in the housing segment of the market. However, the results of the conducted study helped reveal and systematize the problems of property management in the sphere of housing construction, which include lack of proper regulation of enabling properties of the "developer" and "customer" categories; lack of legal clarity as to the identification of the types of contracts concluded between the trustor and developer, especially as to the definition of indicators of targeted use of investors' funds; lack of regulation of identification of the risks which may divest a developer of its status; lack of clarity on the matters of procedures of provision and remuneration of auditor's services, which lowers the transparency of the CFF (RETF) system on the whole; restrictions as to the choice of banking institutions by the developer; absence of a defined algorithm of circulation of property rights in the system of CFF (RETF). The responsibility imposed by the Law on Property Management on CFF (RETF) trustees seems non-symmetric. As this Law does not have separate provisions on the trustees' liability, investors have to join general civil practice. Considering the complexity of the procedure of engaging a trustee in a direct property liability, there are grounds to verify that a CFF (RETF) trustee bears no real onus of property liability before trustors, placing in on the developer instead. However, under the Law on Property Management during House Building, a developer does not enter into contractual relationships with an investor. Thus, the investor is deprived of important leverage of influencing its contractor. Considering this, it would be rational to ensure a more equitable distribution of liability between the trustee and the developer, and putting the developer and investor on the same civil field via signing of bi- or trilateral agreements. The sphere of property management with the use of such securities as RETF certificates is characterized by extremely attractive tax incentives. Such situation is also common in international practice. However, in contrast to

\footnotetext{
${ }^{3}$ More illegal new construction sites in Kyiv (list). Electronic resource. Available at: https://www.unian.ua/economics/realestate/10172558-u-kiyevi-pobilshalo-nezakonnihnovobudov-spisok.
} 
world traditions, the domestic system of RETF investment is not regulated as to other important parameters (the ratio of main income operations, the proportions of profit distribution). This creates potential risks of abuse in this investment area. On the whole, the mechanism of legal regulation of the trustees' activities is rather rigorous. However, the lack of transparency in this sphere limits investors' control options and facilitates corruption. Thus, regulatory and information and analytical support of trust management of property in the housing construction system need further improvement to ensure a balance in the regulation of rights and obligations of trustors, trustees and developers.

Also, it would be expedient to spell out in the law the regulations concerning the change of an inefficient developer. The fact that no control is exerted over double and triple schemes of selling real estate constitute a huge problem. Here, much importance is placed on the developer's reputation. However, currently in Ukraine, a developer's investment portfolio is opened only after a building has been commissioned. It is in practice it can be aware of all future project designs at the stage when it has property rights and effects a sale. If after the sale, property rights for an apartment were entered into a property rights register, it would be impossible to sell this apartment for the second time. It would be expedient to complement Article 4 of the Law of Ukraine "On State Registration of Corporeal Rights to Real Estate and Their Encumbrances" (and other derivative regulations) by a provision on the state registration of property rights to accrual of ownership rights for real estate when investing in construction.

Escrow accounts could become an additional way to protect investors' rights. Internationally, escrow accounts are used along with such tools as collection of payments, letter of credit, debt security. What is an escrow account? It is a current account where the funds are frozen until an event defined by the contract takes place or obligations on account of which the funds were places are fulfilled. For example, if during an operation one party wishes to receive a confirmation that its partner has money at their disposal (or has to provide such proof itself), it opens an escrow account and credits the necessary sum to that account. A more concrete example can be real estate agreements: when a seller settles the agreement terms and conditions with the buyer, the buyer deposits money on an escrow account, which is open for a check by both buyer and seller at any time, but the money can be withdrawn from it only after all terms and conditions have been met and all documents have been signed. Being the escrow agent, the bank monitors the fulfilment of the agreement terms and conditions.

Recently, the National Bank of Ukraine (NBU) announced, that escrow accounts will be launched in Ukrainian banks, and the escrow agent has been 
defined. The regulatory body informs that this is connected with the changes in the legislation, and that the order of opening such accounts for banks has been developed. It is mentioned in the NBU Decision of 18.12.2017 № 133. This document regulates such issues as opening and closing of escrow accounts, defines the list of documents a client has to file to a bank to open such account, the list of operations available for such account, enables foreigners to open such accounts etc. However, today it refers to corporate management in joint stock companies. Moreover, the use of escrow accounts in some cases has become obligatory. Article 65 of the Law of Ukraine "On Joint Stock Companies" provided for a case of an obligatory use of escrow accounts when selling shares upon the demand of a person holding the controlling stake $(95 \%+$ of shares) (squeeze-out). Despite the fact that the concept of an escrow account was virtually absent from the legal system of Ukraine until March 2017, this mechanism was not new for Ukrainian lawyers. Considering that most of large Ukrainian M\&A agreements were concluded with foreign participation under foreign legislation, settlements were often conducted with the participation of foreign banks using escrow accounts. However, escrow accounts have not yet been adequately evaluated and used as a tool to diversify the formation of investment resources in the context of energization of domestic construction companies' activities.

\section{CONCLUSIONS}

Conceptual framework of information and analytical support of trust management of property in the system of housing construction have been developed by forming a comprehensive system of key indicators of the assessment of the activities of trust management schemes in housing development, which synthetizes an integral indicator of a developer's reliability and financial indicators of assessing construction financing funds' and real estate transaction funds' trustees, and accounts for a versatile characterization of existing schemes of investing into real estate on the primary housing market, which allows to create the conditions for equal, transparent and open process of investment implementation in housing construction. The implementation of the proposals made in this work on the improvement of investment mechanisms and control system will allow all investment process participants to balance the liability and reduce investment risks in the residential real estate construction. The methodology of the choice of mechanism enables the management of a construction company to make an optimal choice between the alternatives of investment support of a construction project. 


\section{SUMMARY}

The article provides a definition of structure and criteria of division and differentiation on systematization of investment resources formation sources taking into account specificity of functioning of contract building enterprises, methodological approaches to the analysis of use of financial resources for investment purposes, in their structure characteristic of features of financial maintenance of investment process of the enterprises of housing construction. The basic models of housing financing by the criterion of the mechanism of accumulation of savings and their transformation into investments are classified. This allowed to characterize the domestic model as a transitional bank-oriented one and on this basis to formulate recommendations on its further development prospects by using escrow accounts and introducing state registration of property rights for acquisition of ownership of real estate when investing in construction.

\section{REFERENCES}

1. Bushuiev S.D. Project management under the condition of "behavioral economics" [Text] / S.D. Bushuiev, D.A. Bushuiev, R.F. Iaroshenko // Complex Systems Development Management - 2018. № 33. - pp. 26-30.

2. Econometric tools for managing construction companies' financial security [Text] : [monograph] / [L.V. Sorokina et al.] ; under scientific supervision of professors Sorokina L.V. and Hoiko A.F. - Kyiv : Kyiv National University of Construction and Architecture, 2017. - 403 p.

3. Dotsenko-Belous N.A. Strategies of Construction Financing. - Kyiv: Law Firm "Vasil Kisil and Partners", 2009. - 500 p.

4. Theoretical and methodological framework of innovative and investment activities in Ukraine. / P.M. Kulikov, V.H. Fedorenko, H.M. Ryzhakova et al., collective monograph, LLC "DKS Center", Kyiv 2018. 442 p.

5. Tetyana Marchuk, Dmytro Ryzhakov, Galyna Ryzhakova and Sergiy Stetsenko (2017). Identification of the basic elements of the innovation and analytical platform for energy efficiency in project financing. Investment Management and Financial Innovations (open-access), 14(4), pp. 12-20. DOI: http://10.21511/imfi.14(4).2017.02

6. Pokolenko V.O. Introducing the tools for choosing the alternatives of construction project implementation by functional and technical integrity of implementing organizations / Pokolenko V.O., Ryzhakova G.M., Prykhodko D.O. // Complex Systems Development Management. - 2014. Issue 19. - pp. 104-108.

7. Ryzhakova G. M. Models of targeted choice of representative performance indicators of construction companies: diagnostic systems 
etymology and typology / G.M. Ryzhakova, D.O. Prykhodko, K.M. Predun // Complex Systems Development Management. - 2017. Issue 32. - p. 159-165.

8. Chernyshev D. Implementation of principles of biospheric compatibility in the practice of ecological construction in Ukraine [Text] / D. Chernyshev, I. Ivakhnenko, G. Ryzhakova, K. Predun // International Journal of Engineering \& Technology - UAE: Science Publishing Corporation, 2018- Vol 10, No 3.2: Special Issue 2 - pp. 584-586.

9. Chupryna Y. The identification of alternatives and changes in scenarios for the development of regional build clusters [Text] / Y. Chupryna, D. Ryzhakov, O. Malykhina // International Journal of Engineering \& Technology - UAE: Science Publishing Corporation, 2018 Vol 10, No 3.2: Special Issue 2 - pp. 484-486.

10. Fesun A.S. Improvement of the methodological tools of alternative mechanisms of construction program implementation: changing the management paradigm and innovative financing solutions [Text] / A.S. Fesun // Complex System Development Management. Collection of research papers. - Kyiv: Kyiv National University of Construction and Architecture, 2014. - Issue 19, Part 2 - pp. 122-128.

11. Zeltser, R.Ya., Bielienkova, O.Yu, Novak, Ye.V., Dubinin, D.V. Digital Transformation of Resource Logistics and Organizational and Structural Support of Construction [Text] / Zeltser, R.Ya., Bielienkova, O.Yu, Novak, Ye.V., Dubinin, D.V. // Science and Innovation, 2019 - Vol. 15(5) - pp. 38-51.

12. Izmailova K.V. The essence of economic cycles and their impact on the financial stability of construction [Text] / Izmailova K.V., Bielienkova O.Yu, Moholivets A.A. // Nauk. pr. NDFI, 2019 - Vol. 2 pp. 139-150.

13. Stetsenko S.. The hierarchical model of evaluation of infrastructure risks in construction / S. Stetsenko, T. Ilyina // Nauk. pr. NDFI, 2019. - Vol. 1. - pp. 119-129.

\section{Information about the author: Ryzhakova G. M.,}

Doctor of Economics, Professor, Head of the Construction Management Department Kyiv National University of Construction and Architecture 31, Povitroflotsky Ave., Kyiv, 03037, Ukraine 